\title{
ÇOMÜ Terzioğlu Yerleşkesinde Yaşanabilirlik ve Peyzaj Tasarımı İlişkisi
}

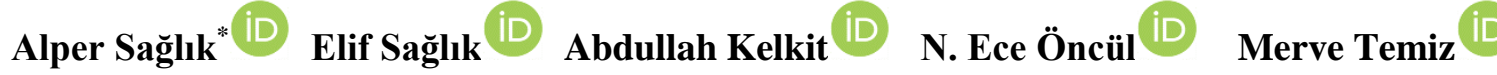

Çanakkale Onsekiz Mart Üniversitesi, Mimarlık ve Tasarım Fakültesi, Peyzaj Mimarlığı Bölümü, Çanakkale

*Sorumlu yazar: alpersaglik@ comu.edu.tr

Geliş Tarihi:29.05.2020

Kabul Tarihi: 06.07.2020

\section{$\ddot{\mathbf{O} z}$}

Üniversite yerleşkeleri; içerisinde eğitim yapıları, sosyal tesisler, lojmanlar vb. birçok açık veya kapalı mekanı bir arada bulunduran açık yeşil alanlardır. Önemli bir kent unsuru olan yerleşkeler, kentsel dokuya önemli katkı sağlamaktadır. Bünyesindeki çalışan ve öğrenci potansiyeli ile bunların kullanımına sunulan açık ve kapalı mekanları barındıran üniversiteler, kentlere yaşanabilir alanlar oluşturmaktadır. Üniversite yerleşkeleri, açık ve yeşil alanlarındaki bitkiler ve kentsel donatı elemanları ile kullanıcıların yaşam kalitelerini artırmaktadır. $\mathrm{Bu}$ çalışmada; Çanakkale Onsekiz Mart Üniversitesi Terzioğlu Yerleşkesi için yaşanabilirlik derecesini arttırmaya yönelik olarak mevcut durumdaki çevresel şartlar ve yaşam kalitesini oluşturan ölçütler; aktivite ve kullanımlar, ulaşılabilirlik, konfor ve imaj, sosyallik başlıkları altında tespit edilmiş ve değerlendirilmiştir. Çalışma sonucunda üniversite yerleşkesi dış mekanlarında malzeme ve uygulama kaynaklı birçok sorun tespit edilmiştir. Bu sorunların nedenleri araştırılarak çözüm önerileri getirilmiştir.

Anahtar Kelimeler: ÇOMÜ, üniversite, yerleşke, peyzaj tasarımı, yaşanabilirlik

\section{Relationship between Liveability and Landscape Design at COMU Terzioğlu Campus Abstract}

University campuses in educational buildings, social facilities, housing and so many are open or closed space containing a combination of open green space. Settlements, which are an important city element, make an important contribution to the urban texture. Universities, which include open and closed spaces offered to the employees and the potential of employees and students, constitute livable areas for cities. University campuses increase the quality of life of users with plants and urban reinforcement elements in open and green areas. In this study; Canakkale Onsekiz Mart University Terzioğlu Campus aims to increase the level of livability and current environmental conditions and criteria that make up the quality of life; activities and uses were determined and evaluated under the headings of accessibility, comfort and image, sociability. As a result of the study, many problems related to material and application were determined in the outer spaces of the university campus. The causes of these problems were investigated and solutions were proposed

Keywords: COMU, university, campus, landscape design, livability

\section{Giriş}

Kentsel yaşamın varoluşu ile birlikte kentlerde, fiziksel ve fonksiyonel açıdan birçok değişim ve dönüşüm meydana gelmiştir. Bu değişimin kontrolsüz bir şekilde ilerleyişi, mekanların fiziksel kalitesini ve kent yaşamını olumsuz etkilemiştir. Kent düzeyinde ihtiyaçlara cevap veremeyen hizmetler, kentsel gelişime de imkan sağlayamamıştır (Öztürk ve Özdemir, 2013). İnsanoğlunun bulunduğu çevre ve yaşam kalitesi arasında kuvvetli bir bağ vardır. Yaşam kalitesini belirleyen ölçütler aynı zamanda bulunduğu fiziksel mekanın da kalitesini etkilemektedir. Yaşam kalitesi bireylerin ve toplumların refah ve kolay erişimini ifade eden bir kavramdır. Dünya Sağlik Örgütü (WHO)'ne göre yaşam kalitesi; bireylerin toplum içerisindeki yaşamları, kültürel değerleri anlama değerlendirme biçimi olarak tanımlanmaktadır (Yıldırım ve Hacıhasanoğlu, 2011). Dünya nüfusunun buna bağlı olarak da kentli nüfusunun artması ve küreselleşme ile meydana gelen çevresel tahribatlar nedeniyle yaşam kalitesini ve kentsel gelişimi sağlıklı bir şekilde artıracak planlama çalışmalarının yapılması son derece önemlidir.

Kentsel gelişim için toplumda yaşayan bireylerin ihtiyaçlarına cevap vermek ve onlara kaliteli bir yaşam sunmak gerekmektedir. Bunu sağlayacak olan yaşam kalitesi; alt yapı ve sosyal donatı alanları gibi fiziksel bileşenleri içermektedir. Bu bileşenler içerisinde yer alan açık yeşil alanlar peyzaj tasarım ve planlama çalışmaları açısından önemli bir yere sahiptir (Bağc1, 2010). 
Kentsel açık yeşil alanlar park, bahçe, dinlenme alanları, oyun ve spor alanları gibi rekreatif ihtiyaçlara karşılık ya da orman, göl, tarım alanları gibi arazi kullanımlarına imkan sağlayan kent içinde veya dışında kalan alanlar olarak tanımlanmaktadır (Yıldızcı, 1982). Açık yeşil alanlar; kentlilerin yaşam kalitesini olumlu yönde etkileyen, kenti çekici kılarak kent imajına olumlu katkılar sağlayan ve rekreasyonel kullanım potansiyeli olan alanlardır (Oğuz, 1998). Kentsel açık yeşil alanların yeterli düzeyde olması bireylerin yaşam kalitesini ve verimliliğini önemli ölçüde artıracaktır. Kent içerisinde bulunan meydanlar, kamusal alanlar, kıyı alanları, kent parkları, hayvanat bahçeleri, üniversite yerleşkeleri gibi alanlar yeşil alanların potansiyelini artırmak için önemli alanlardır (Tanrıverdi, 1975; Pamay, 1979; Ertekin ve Çorbacı, 2010).

Latince bir kelime olan ve diğer dillere yayılan üniversite kelimesi ilk olarak 'universitas' olarak kullanılmıştır. Universium, universal ve universas kelimelerinin zaman içerisinde farklılaşmasıyla ilk üniversitelerin kurulduğu Orta Çağ' da tüzel kişilerin oluşturduğu birlik anlamında kullanılmıştır. Tarihsel süreçte 'universitas literarum' adını alarak bilim birliği anlamını taşımıştır (Sönmezler, 2003). Eğitim öğretim faaliyetlerinin yanında kent için önemli bir açık yeşil alan olan üniversite yerleşkelerinin tasarımı çok önemlidir. Üniversite yerleşkeleri birbirinden bağımsız birçok mekana sahiptir bu nedenle aradaki bağı kuvvetlendirecek ve tüm kullanıcılar için kolay erişim sağlanabilecek peyzaj tasarımına ihtiyaç vardır. Bu alanların peyzaj tasarım kriterleri doğrultusunda planlanıp tasarlanması, kullanıcıların güvenli ve kaliteli bir ortamda yaşamalarını sağlayacaktır (Ertekin ve Çorbac1, 2010).

Üniversite yerleşkelerinin tasarımı; içerisinde bulunan kişilerin fiziksel ve psikolojik sıkıntı ve kaygılarından uzaklaştırıcı, dinginlik sağlayarak sosyalleşme ve fiziksel aktivitelere olanak sağlayacak şekilde olmalıdır. Bu etmenler dikkate alındığında üniversitelerin eğitim ve öğretim kalitelerinde de önemli ölçüde artış olacaktır (Yılmaz, 2015). Bu kapsamda Çanakkale Onsekiz Mart Üniversitesi Terzioğlu Yerleşkesi için yaşanabilirlik derecesini arttırmaya yönelik olarak mevcut durum analizi yapılarak değerlendirme yapılmıştır. Değerlendirmeler sonucunda elde edilen sorunlara yönelik öneriler geliştirilmiş̧ir.

\section{Materyal ve Yöntem}

Araştırmanın ana materyalini Çanakkale Onsekiz Mart Üniversitesi Terzioğlu Yerleşkesi (Şekil 1) oluşturmaktadır. Çalışma, yerleşkede malzeme ve uygulama kaynaklı eksikliklerin tespit edilmesi, yaşanabilirlik ve peyzaj tasarım ilisskisinin ortaya koyulması amacıyla yapılmıştır.

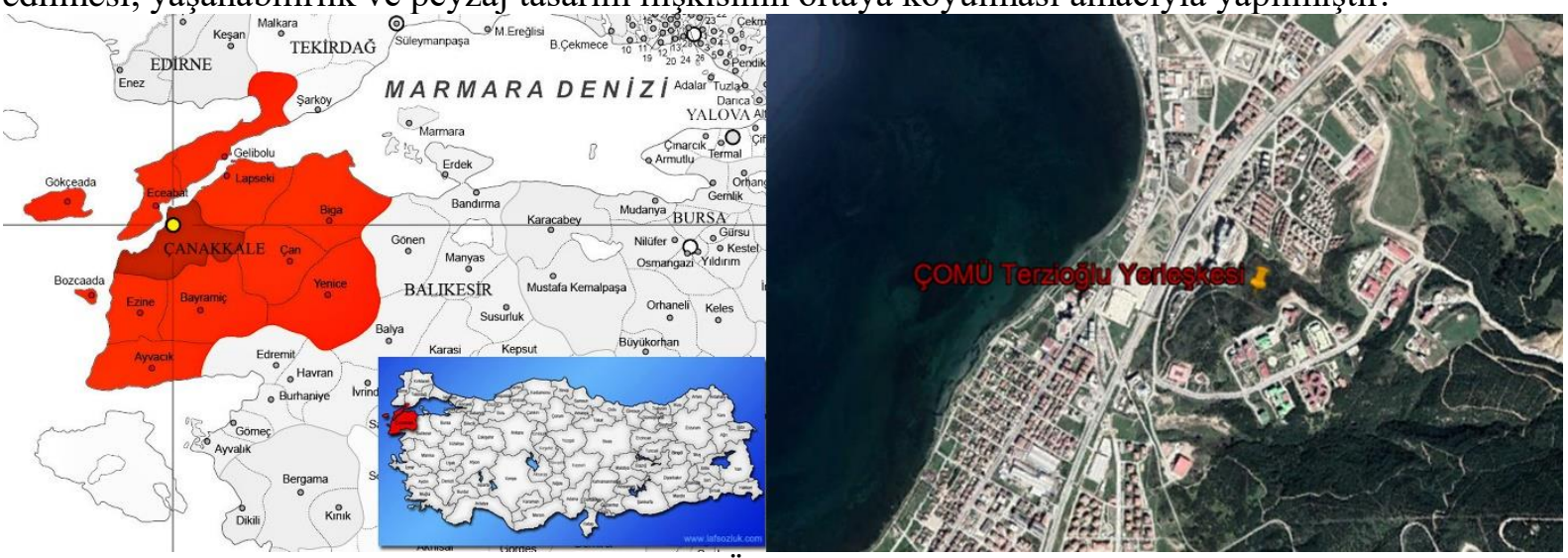

Şekil 1. Çanakkale Onsekiz Mart Üniversitesi Terzioğlu Yerleşkesi konumu

Terzioğlu Yerleşkesi’nin araştırma alanı olarak seçilmesinin temel nedenleri:

- Çanakkale Onsekiz Mart Üniversitesi'nin idari ve akademik birimlerinin önemli bir kısmının bu yerleşkede yer alması.

- Çanakkale-İzmir Karayolu ana geçiş güzergahı ve bağlantı yollarının merkezinde olmasi.

- Araştırma alanı, Çanakkale Boğazına hakim bir noktada olması.

- Alanın Çanakkale Boğazının karşısında konumlanmasının yanı sıra, orman örtüsünce zengin yakın çevresi ile de rekreasyon açısından zengin bir potansiyele sahip olması. 
- Çevredeki rekreasyonel doğal kaynakların zenginliği ve günübirlik kullanılabilirliği, yerleşke rekreasyon alan ve mekanlarını öncelik sıralamasında geri plana itmiş olabilir.

- $\mathrm{Bu}$ doğrultuda yerleşkedeki mevcut rekreasyon alanlarının yaşanabilirlik bakımından öneminin sorgulanması gerekliliği ortaya çıkmaktadır.

Araştırmanın yöntemi; veri ve literatür toplama, kimlik kartlarının oluşturulması, rekreasyon alanları ile ilgili kalite ölçütlerinin (Kalite Ölçüt Karneleri Yöntemi) hazırlanması, analiz, sentez ve önerilerin geliştirilmesi olmak üzere değişik aşamalardan oluşmaktadır. Terzioğlu Yerleşkesinde yaşanabilirlik açısından üniversiteyi temsi etmesi ve seçilen alanların mevcut durumlarının tespit edilmesi amacı ile her alana özgü kimlik kartı kurgulanmıştır.

\section{Kalite Ölçüt Karne Yöntemi}

Bir alanın tasarımı yapılırken o alanın ihtiyaçlara cevap verebilmesine ve fonksiyonel olmasına dikkat edilmelidir. Yapılan tasarımın doğruluğunu alanın aktifliği, konfor ve imajı, alan kullanımları ve sosyallik durumları gibi ölçütler belirler (Şekil 2). Bu ölçütler kullanılarak alanın kullanıcılar tarafından nasıl algılandığı ve alanı daha yaşanabilir ve kaliteli bir hale nasıl getirilebileceği tespit edilir (Sağlık, 2014).

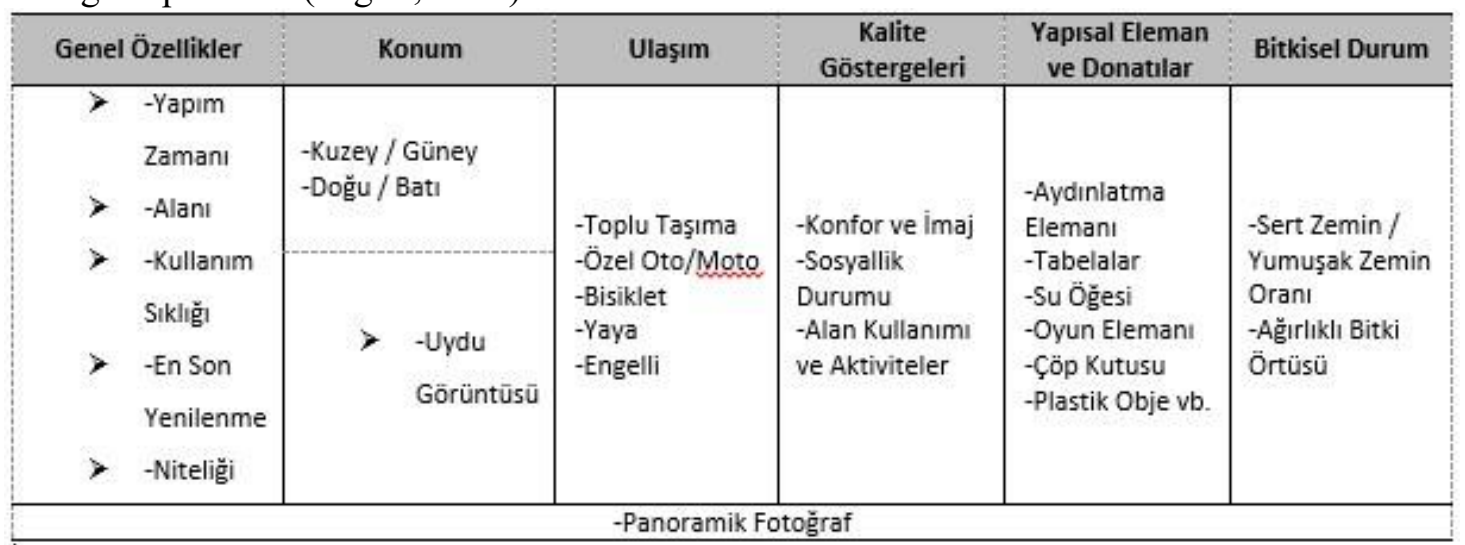

\section{Kimlik Kartlarının Oluşturulması}

Şekil 2. Kimlik kartı içinde yer alan ölçütler

Çanakkale Onsekiz Mart Üniversitesi Terzioğlu Yerleşkesi açık yeşil alanları, kenti temsil etmektedir. Yerleşke içerisinde dış mekanların tasarımına yönelik mevcut durumun ve sorunların tespit edilmesi amacıyla her alana özgü birer kimlik kartı oluşturulmuştur. Bu kimlik kartlarında daha önce belirlenmiş kalite ölçütleri detaylandırılarak alanın tanımlanması sağlanmıştır. Yerleşke içerisinde bulunan tüm yapıların çevresi ve açık yeşil alanlar için kimlik kartları hazırlanmıştır.

\section{Bulgular ve Tartıșma}

Tarihsel Gelişimi 3 Temmuz 1992 tarihinde, 3837 sayılı kanunla kurulan Çanakkale Onsekiz Mart Üniversitesi, 1992-1993 Eğitim-Öğretim yılında Trakya Üniversitesi'nden devredilen Çanakkale Eğitim Fakültesi, Çanakkale Meslek Yüksekokulu ve Biga Meslek Yüksekokulu ile eğitim-öğretim hayatına başlamıştır. Çanakkale Onsekiz Mart Üniversitesi'nin ana yerleşkesi Çanakkale-İzmir karayolu kavşağında bulunan ve üniversitenin ana birimlerini bünyesinde barındıran Terzioğlu Yerleşkesi'dir (Şekil 3) (Anonim, 2020a). 1993 yılı ve sonrasında çeşitli fakülte, meslek yüksekokulu, enstitü, sosyal tesis olmak üzere birçok birim üniversitede eğitim-öğretim dönemine başlamıștır.

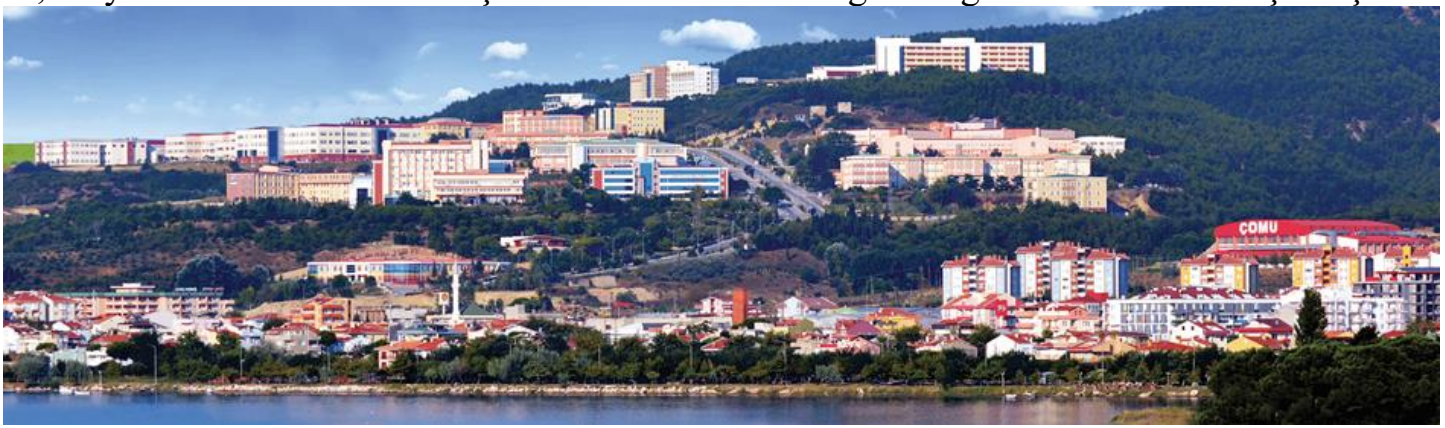

Şekil 3. Çanakkale Onsekiz Mart Üniversitesi Terzioğlu Yerleşkesi 
Yerleşkeler bulunduğu kente aidiyet kazandıran önemli açık yeşil alanlardır $\mathrm{Bu}$ nedenle Terzioğlu Yerleşkesi'nde belirlenen araştırma alanlarının yaşanabilirlik açısından mevcut durumlarının değerlendirilmesi için Rektörlük binası ve yerleşke içerisinde yer alan fakülteler için kimlik kartları hazırlanmıştır (Şekil 4, 5, 6, 7, 8, 9, 10, 11, 12, 13).

\section{COMÜ Rektörlük Binası ve Cevresi}

Terzioğlu Yerleşkesi ilk temsili binası konumunda olan Rektörlük binası, biri üç diğeri altı katlı olmak üzere birbirine bitişik iki binadan oluşmaktadır Rektörlüğe bağlı 5 adet Bölüm Başkanlığı bulunmaktadır. Rektörlük idari yapısında ise, 8 Daire Başkanlığı ve Üniversitemiz Genel Sekreterliği bünyesinde ise 9 adet Koordinatörlük bulunmaktadır (Anonim, 2020a). Yapılan incelemeler ve gözlemler sonucunda rektörlük binası çevresiyle ilgili saptanan sorunlar şunlardır: Rektörlük karşısındaki kütüphane tarafi girişindeki kaldırımlar yıpranmış ve yerinden çıkmış durumdadır. Izgarayı çevreleyen betonda kırıklıklar mevcuttur. Otopark içindeki yeşil alan olarak ayrılmış duvar kenarlarını yabancı otlar istila etmiştir. Otopark girişindeki kaldırımda çok fazla çökme tespit edilmiştir. Rektörlük karşısından başlayıp ana girişe inen merdivenlerde kırılmalar ve yer yer beton dolgular mevcuttur. Rektörlük binası B blok yanındaki otopark girişindeki bordürler karşılıklı olarak neredeyse zeminle aynı hizaya gelmiş durumdadır. A blok girişinin karşısındaki oturma birimlerinin üzerine gölgelendirme amacıyla yapılan kısım boşluklu olduğundan gölgelendirme işlevini yapmıyor ve gölgelendirme amacı ile herhangi bir bitki ile sarılmamıştır. B blok girişi önündeki kameriyelere girişte yol kotu, kaldırım kotundan yüksekte olmakla beraber, palmiye bitkisi kameriye girişindeki yolu engellemektedir. B blok girişinin otopark tarafindaki rampanın döşemelerinde kırıklar tespit edilmiştir ve rampanın her iki tarafında da herhangi bir korkuluk olmadığı saptanmıştır.

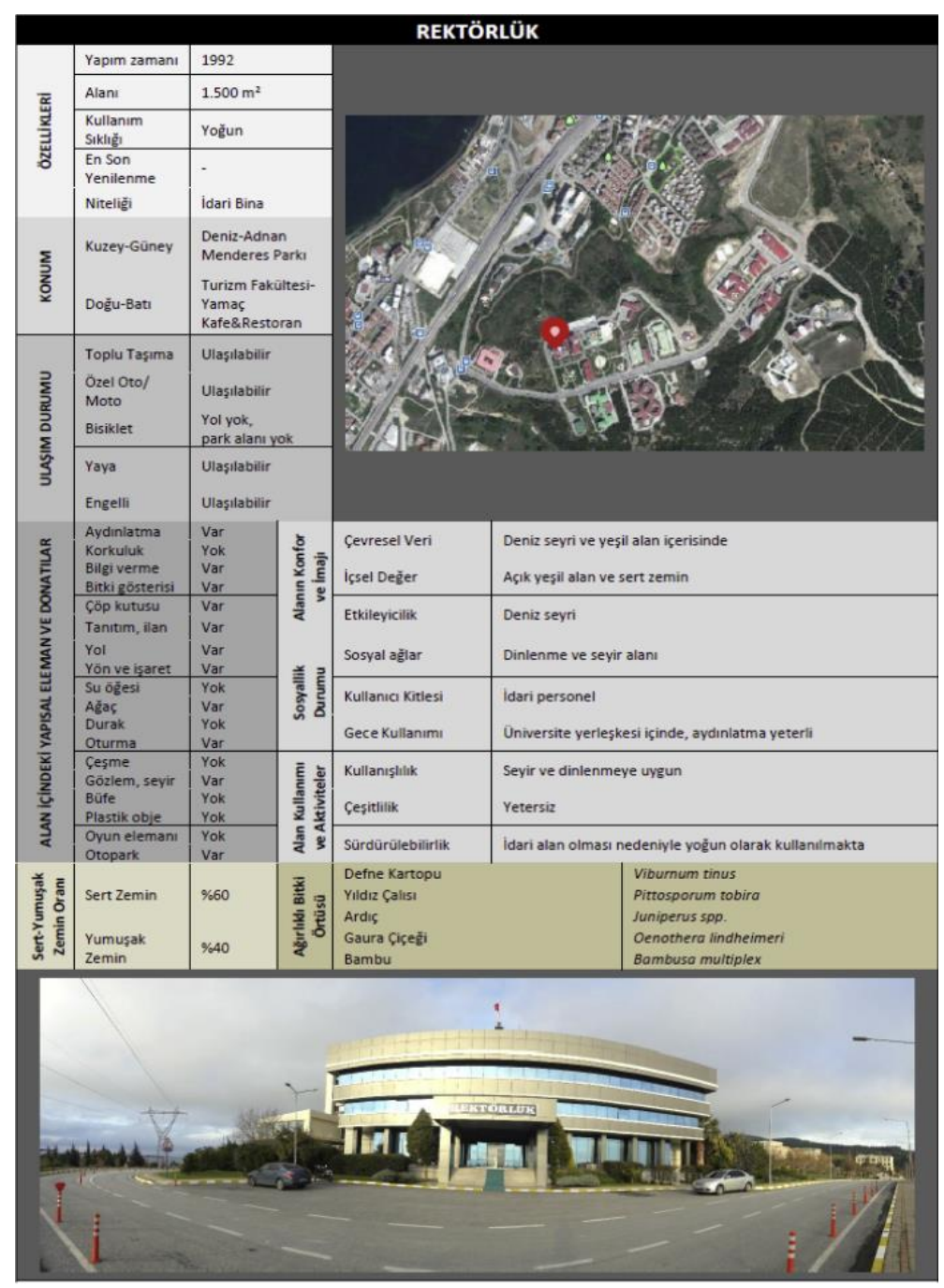

Şekil 4. Rektörlük binası ve çevresi kimlik kartı 


\section{ÇOMÜ Tıp Fakültesi Binası ve Çevresi}

3 Temmuz 2000 tarihinde Bakanlar Kurulu kararı ile kurulan Çanakkale Onsekiz Mart Üniversitesi Tıp Fakültesi, 2007 yılından itibaren kendi binalarında eğitim vermeye başlamıştır (Anonim, 2020b). Yapılan incelemeler ve gözlemler sonucunda yerleşke tıp fakültesi dekanlığı çevresiyle ilgili saptanan sorunlar şunlardır: Kaldırımlarda birçok yerde çökme tespit edilmiştir. Otoparka girişteki ızgara eski tip olup kullanılamayacak durumdadır ve sağ taraftaki kaldırımlar bitkiler tarafından kapatılmıştır. Otopark tabelası bitkiler tarafından fark edilemeyecek duruma gelmiştir. Tıp Fakültesi dekanlık binasının arka tarafı yığılmış parke taşları ve bakımsız bahçe yüzünden görüntü kirliliği oluşturmaktadır. Alanın yan tarafında bulunan kanal çöp birikintisiyle tıkanmıştır. Binanın yola bakan bahçesindeki çimler ve yabancı otlar bahçeyi bakımsız gösterirken, kenara yığılan harç ve parke taşları da aynı etkiyi bırakmaktadır. Bahçede bulunan spor aletleri yabancı otların arasında kaybolmuştur. Bina yanındaki basket sahasının içerisi yabancı ot istilasına uğramıştır.

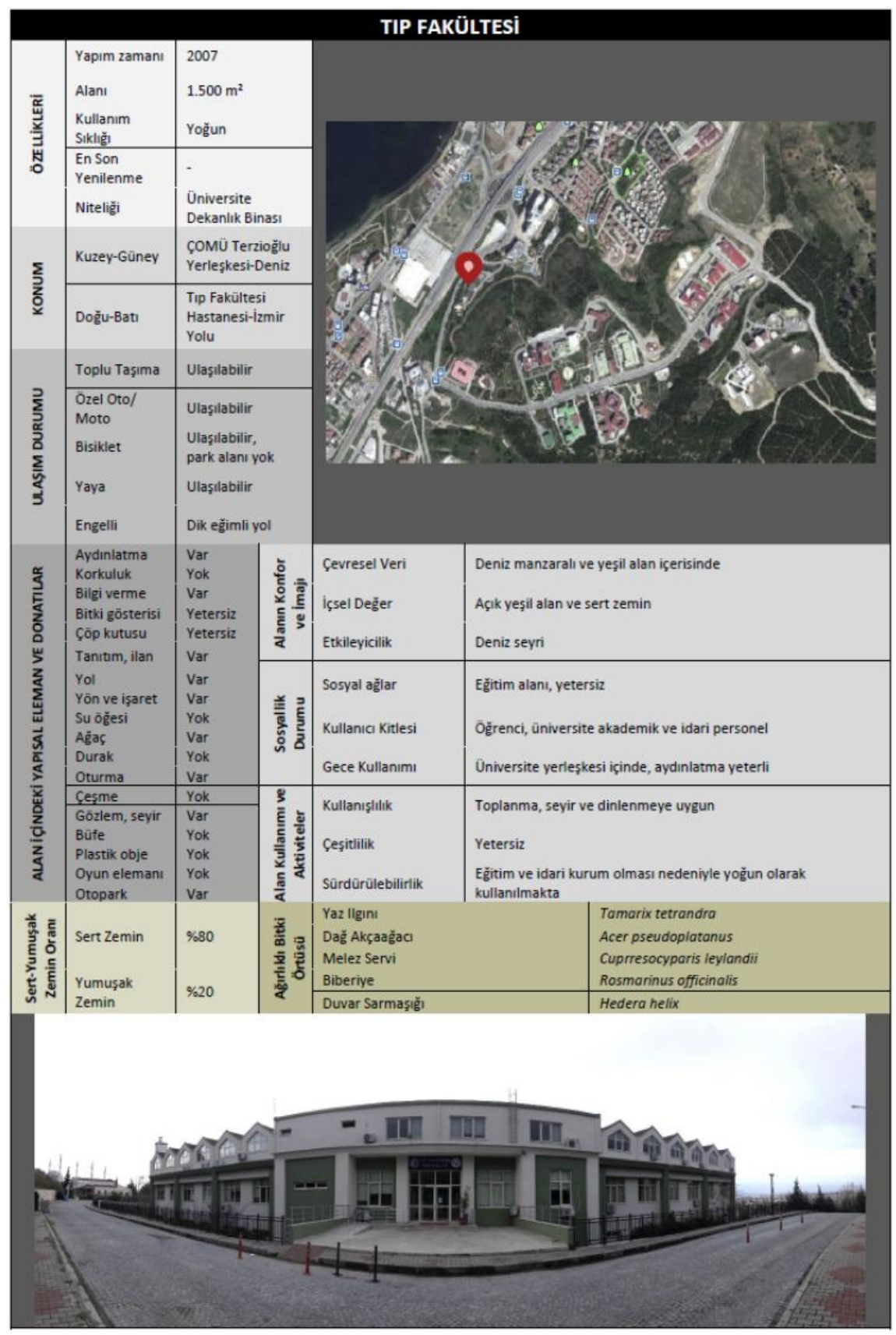

Şekil 5. Tıp fakültesi binası ve çevresi kimlik kartı 


\section{ÇOMÜ Siyasal Bilimler Fakültesi Binası ve Çevresi}

08.03.2012 tarih 28.277 say1lı Resmi Gazete'de yayımlanan 201272734 say1lı Bakanlar Kurulu kararı ile 16.01.2012 tarihinde Terzioğlu Yerleşkesi'nde 11 bölümle İktisadi ve İdari Bilimler Fakültesi olarak açılmıştır. Daha sonra Çanakkale Onsekiz Mart Üniversitesi Rektörlüğ̈̈'ne bağlı İktisadi ve İdari Bilimler Fakültesi "Siyasal Bilgiler Fakültesi”" olarak değiştirilmiş ve 08.04.2016 tarih ve 29678 sayılı Resmi Gazete'de yayımlanmıştır (Anonim, 2020c). Yapılan incelemeler ve gözlemler sonucunda fakülte ve çevresiyle ilgili saptanan sorunlar şunlardır: Kantin önüne konulan babalar girişi engellemediği için gereksiz durumdadır. Kantin ve ÖSEM arasındaki klima boruları aşağıya kadar indirilmediği için kantinde oturanlara ve orada geçenlerin üzerine su damladığı gözlemlenmiştir. Bina ve ÖSEM tarafında kaldırım kesişiminde açıklıklar ve doğalgaz kutusunun önünde derin bir çökme mevcuttur. Bina önündeki anıtın mermerleri bakımsızlıktan düşmüştür. Bina önündeki anıtın altındaki havuz bakımsız, temizlenmiyor ve anıtın kenarında atıl duran kontroplak görüntü kirliliği oluşturmaktadır. Binanın ana yol tarafındaki kaldırımının üzerindeki ağaçların altındaki zemin, kaldırım kotundan yüksekte kalmış durumdadır. Binanın önündeki parkın ana yol tarafındaki kaldırımda, üst taraftaki kaldırım gibi ağaç köklerinin etkisiyle kot farkı oluşmuştur.

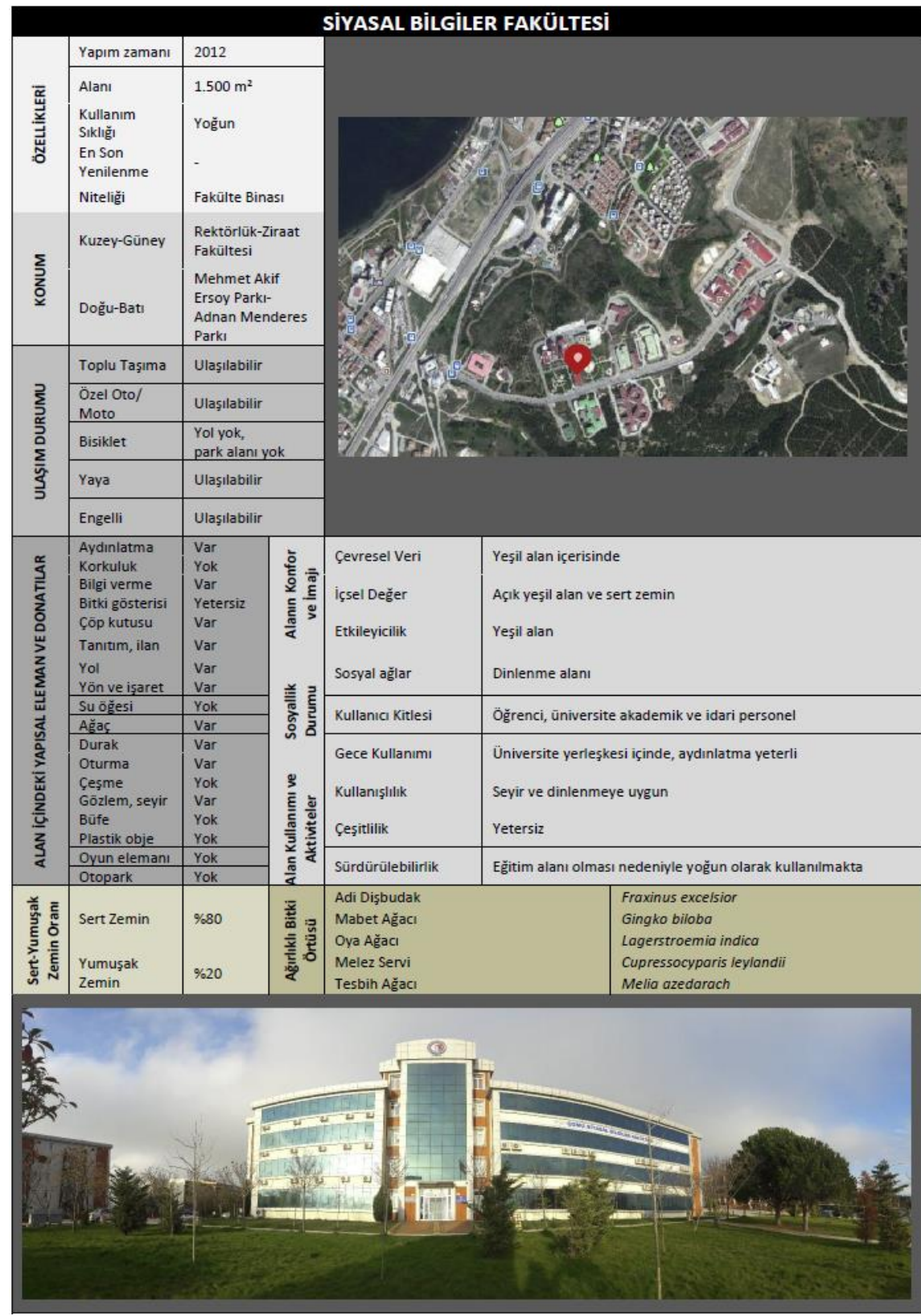

Şekil 6. Siyasal bilimler fakültesi binası ve çevresi kimlik kartı 


\section{ÇOMÜ Turizm Fakültesi Binası ve Çevresi}

Fakülte 1993-1994 eğitim-öğretim yılında eğitime başlamıştır. 2013-2014 Eğitim-Öğretim yılından itibaren ismi Turizm Fakültesi olarak değişmiştir. 2014-2015 Eğitim-Öğretim yılından itibaren ise Konaklama İşletmeciliği Bölümü, Turizm İşletmeciliği olarak eğitime devam etmektedir (Anonim, 2020d). Yapılan incelemeler ve gözlemler sonucunda yerleşke ana girişi ve güvenlik kulübesi çevresiyle ilgili saptanan sorunlar şunlardır: Kütüphane eski binası Turizm Fakültesi yanındaki kaldırımlarda çökmeler mevcut ve refüjler yabancı ot istilasına uğramıştır. Bina girişi yanı yabancı ot istilasına uğramış ve bakımsız durumdadır. Rektörlük ve bina arasındaki otoparkta yan kapının sol tarafında bordürsüz yeşil alan tespit edilmiştir.

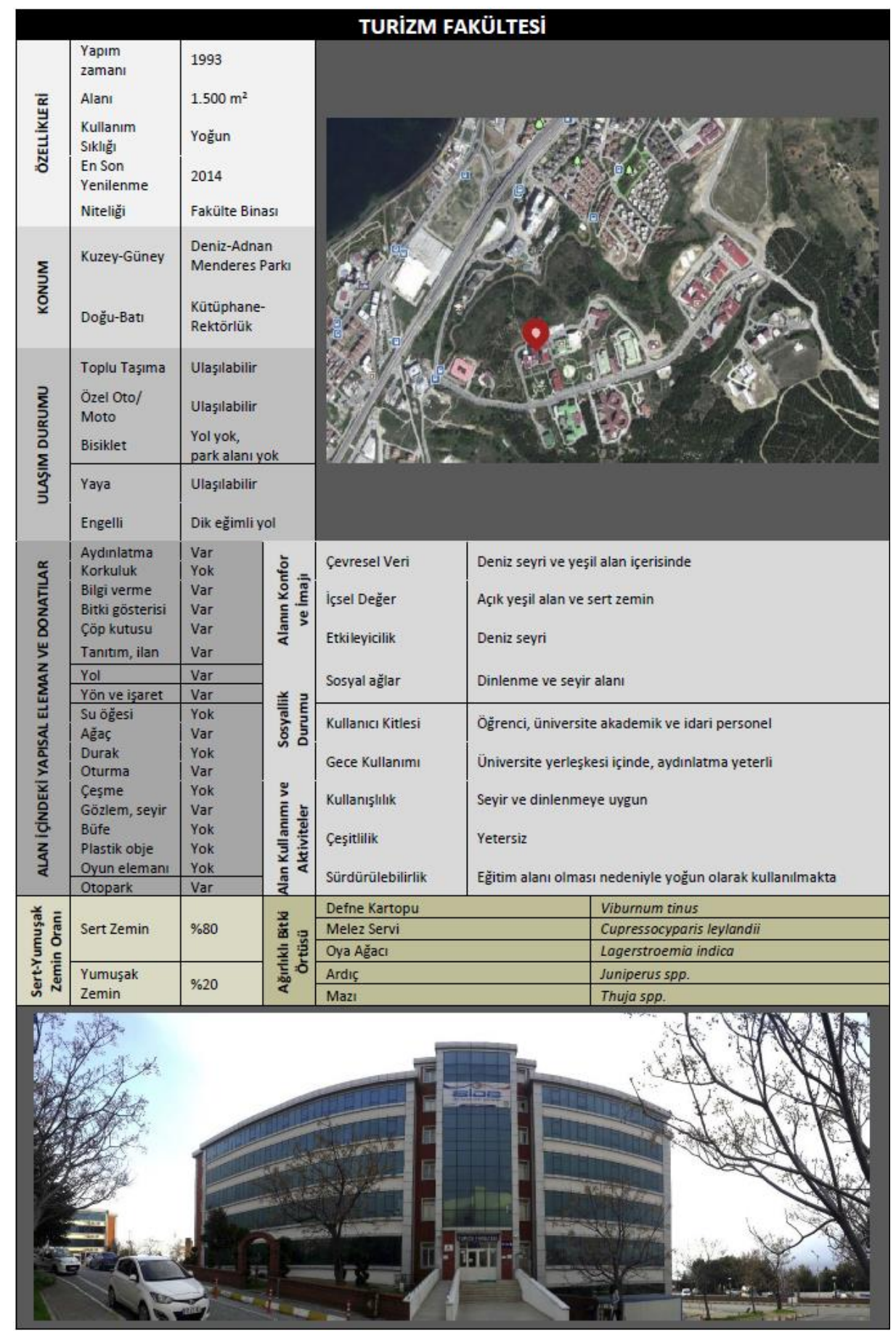

Şekil 7. Turizm fakültesi binası ve çevresi kimlik kartı 


\section{ÇOMÜ Ziraat Fakültesi Binası ve Çevresi}

11.07.1992 tarihinde kurulan fakülte, 1995-1996 eğitim-öğretim y1lında Bahçe Bitkileri ve Zootekni bölümlerine öğrenci alarak öğrenime başlamıştır. 2001-2002 öğrenim y1lından itibaren yerleşkedeki $13.600 \mathrm{~m}^{2}$ alana sahip binasına taşınmıştır (Anonim, 2020e). Yapılan incelemeler ve gözlemler sonucunda fakülte ve çevresiyle ilgili saptanan sorunlar şunlardır: Ziraat Fakültesi tabelasının önündeki bordürlerde kırıklar tespit edilmiştir. Tabelanın yanından başlayıp fakülteye giden kaldırım yabancı ot istilasına uğramış durumdadır. Mehmet Akif Ersoy Parkı tabelası yüksek boylu bitkilerin arasında kalmıştır. Ziraat Fakültesi dekanlık otoparkına girişte sağ taraftaki zeminde çökme tespit edilmiştir. Fakültenin dekanlık ve kantin arasında kalan girişinin önündeki zeminde döşeme taşları kırılmış ve tamamlanmamıştır. Fakülte yan bina girişinde rampa mevcut değildir. Yan giriş önündeki eski harman makinasında yenilenmesi gereken bölümler tespit edilmiştir. Yer yer çürümeler ve paslanan kısımlar bulunmaktadır. Kantin girişi sağ tarafında binanın zemine yaklaşan yerinde bir delik mevcuttur. Hemen önündeki kaldırımda da kırık ve eksik parke taşları tespit edilmiştir. Fakülte bahçesi sol tarafındaki otopark girişinde çöp ve kağıt toplama kutusu rasgele konulmuş ve yolun ortasında kalmıştır.

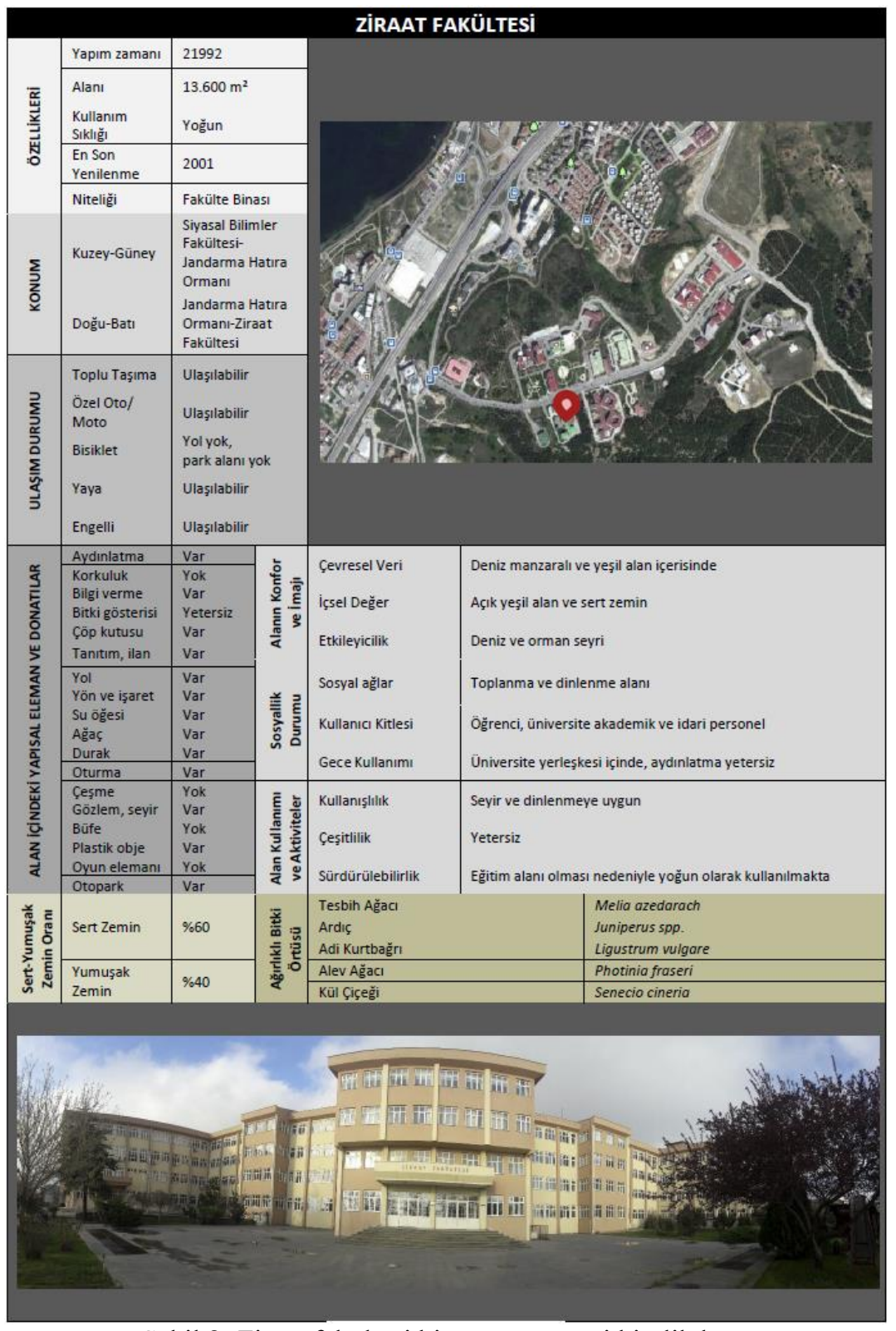

Şekil 8. Ziraat fakültesi binası ve çevresi kimlik kartı 


\section{ÇOMÜ Fen Edebiyat Fakültesi Binası ve Çevresi}

1993-1994 eğitim- öğretim yılında faaliyete geçen fakülte binasında 9'u teknik donanıma sahip olmak üzere 30 derslik, 3 bilgisayar laboratuvarı, Fizik, Kimya, Biyoloji, Coğrafya, Arkeoloji ve Sanat Tarihi bölümlerine ait araştırma ve öğrenci laboratuvarları ile Tarih ve Sanat Tarihi bölüm kütüphaneleri ve okuma salonları yer almaktadır (Anonim, 2020f). Yapılan incelemeler ve gözlemler sonucunda fakülte ve çevresiyle ilgili saptanan sorunlar şunlardır: Fen Edebiyat Fakültesinin yanına yapılan oturma alanı altı boş olduğundan pek güvenli görünmemektedir. Fakültenin bahçe girişinde köşede bulunan kültür merkezi tabelası, önündeki bitki yüzünden görülemeyecek durumdadır. Sol yan girişinde çok bakımsız bitki parteri bulunmaktadır ve arka girişi hurdalığa dönüştürülmüştür. B blok arkasında yangın merdivenin başladığı alandaki yağmur suyu olukları sert zemine verilmiştir. B blok girişi önündeki otoparkta zeminde eksik alanlar mevcut ve mazgallar, içerden çıkan yabancı otlar yüzünden yerinden çıkıp zemin seviyesinin üzerine yükselmişlerdir. Fakülte personel girişi önündeki bahçede, bahçeye çıkan merdivenlerde kırılmış bölümler ve bahçe ortasındaki sert zemin döşemeleri arasından çıkmış yabancı otlar mevcuttur. Aynı zamanda bitkiler bakımsız ve budanmaya ihtiyacı olduğu tespit edilmiştir. Personel girişi kapısı önündeki bahçenin kenarındaki kaldırımlar yeşil alanla bir bütün oluşturmuş, kaldırımlar görünmemektedir ve bordürleri son derecede yıpranmıştır.

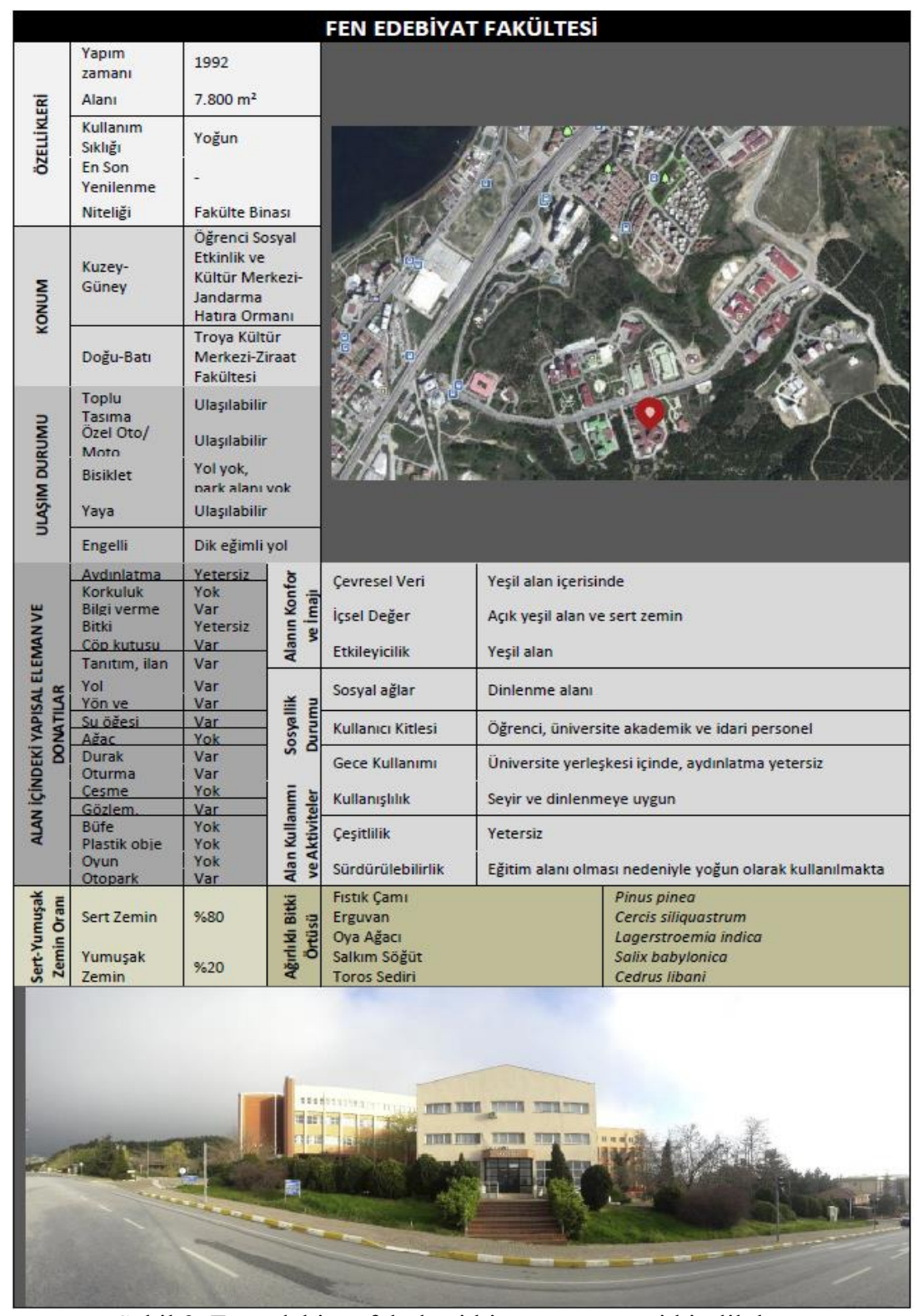

Şekil 9. Fen edebiyat fakültesi binası ve çevresi kimlik kartı 


\section{ÇOMÜ Deniz Bilimleri ve Teknolojisi Fakültesi Binası ve Çevresi}

1992 y1lında Ezine Üvecik’te eğitim-öğretime başlayan fakülte, 2004-2005 y1lında Terzioğlu Yerleşkesine taşınmıştır. Fakülte $6.000 \mathrm{~m}^{2}$ alana sahiptir. Fakülte içinde Temel Bilimler, Yetiştiricilik, Avlama ve İşleme teknolojisi olmak üzere üç farklı bölüm ve Piri Reis Deniz Müzesi ve Galerisi bulunmaktadır (Anonim, 2020g). Yapılan incelemeler ve gözlemler sonucunda fakülte ve çevresiyle ilgili saptanan sorunlar şunlardır: Binanın ön tarafında kaldırım kenarındaki bakımsız ve toprak alanda kantin işletmecisinin gelişigüzel koyduğu tabela görüntü kirliliği oluşturmaktadır. Binanın ana yola yakın tarafındaki çöp kutuları gelişigüzel konulduğu gibi aşırı derecede kötü kokusu (balık atıkları) yoldan geçenleri dahi rahatsız edecek boyuttadır. Taş değirmenin önündeki ve karşısındaki kaldırımlar yabancı otların istilasına uğramış durumdadır. Binanın kalorifer dairesinin ön tarafında kalan köşede zeminde çökmeler meydana gelmiştir. Binanın denize bakan tarafına rasgele konulan masalar ve sandalyeler hem görüntü kirliliği oluşturmuş hem de üstlerinde herhangi bir kapatma elemanı bulunmadığından işlevsiz durumdadırlar. Binanın yan tarafındaki havuz ve çevresi bakımsız durumdadır. Havuzun içinde balık yaşamasına rağmen dibi görünmeyecek kadar kirlidir. Bina girişindeki rampanın eğimi uygun ölçülerde değildir.

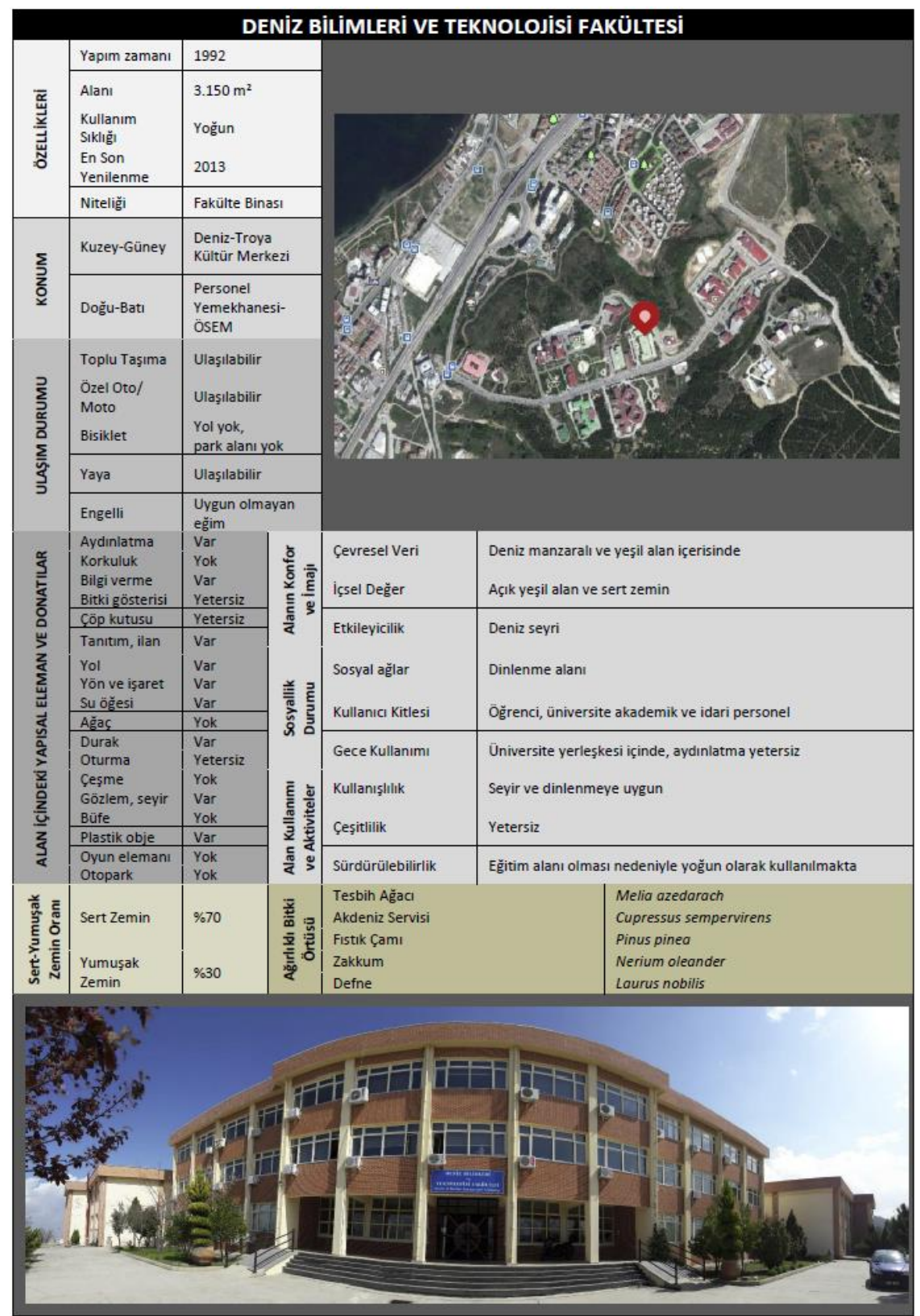

Şekil 10. Deniz bilimler ve teknolojisi fakültesi binası ve çevresi kimlik kartı 


\section{ÇOMÜ Güzel Sanatlar Fakültesi \& Mimarlık ve Tasarım Fakültesi Binası ve Çevresi}

Toplam $15.000 \mathrm{~m}^{2}$ lik alana sahip bina 3 fakülteyi birlikte barındırmaktadır. 2012 yılında yeni binasına geçen Güzel Sanatlar Fakültesi görsel ve işitsel birçok anabilim dalıyla eğitim faaliyetine geçmiştir. Mimarlık ve Tasarım Fakültesi, 2012 yılında kurulmuş olup, bünyesinde Peyzaj Mimarlığı, Mimarlık, Şehir ve Bölge Planlama, İç Mimarlık ve Endüstri Ürünleri Tasarımı Bölümlerini anabilim dalları ile birlikte barındırmaktadır. 2011 yılı kurulan İletişim Fakültesi, Radyo-Sinema ve Televizyon, Gazetecilik, Görsel İletişim Tasarımı, Halkla İlişkiler ve Reklamcılık, Yeni Medya ve İletişim Bilimleri olmak üzere altı bölüme sahiptir (Anonim, 2020h). Yapılan incelemeler ve gözlemler sonucunda fakülte ve çevresiyle ilgili saptanan sorunlar şunlardır: Bina önünde denize karş1 atıl vaziyette kalmış büyükçe bir alan bulunmaktadır. Bina öğrenci girişinin bahçesinde yaza ve kışa uygun üzeri kapalı oturma birimleri bulunmamaktadır. B kapısı önündeki parke taşlarının arasından çok sayıda yabancı ot çıkmıştır. Binadan saat kulesine gidilen kaldırımda diğerlerinden farklı yükseklikteki bordür yaya kazasına yol açabileceği tespit edilmiştir. Durağın sağ tarafındaki çöp kutusu da eğimin etkisi ile deforme olmuştur. Bina arkasında durak yüzünden daralan kaldırımın kullanılacak kısmındaki parke taşları düzgün döşenmemiştir. Binanın arkasındaki ana yol yanındaki yamaçtaki bitkiler kurumuştur. Bina arkasındaki yamaçta gereksiz beton kütleleri tespit edilmiştir. C kapısına ana yoldan inen merdivenlerin başlangıcındaki prefabrik binanın önündeki kaygan zeminde eksik döşeme elemanı vardır.

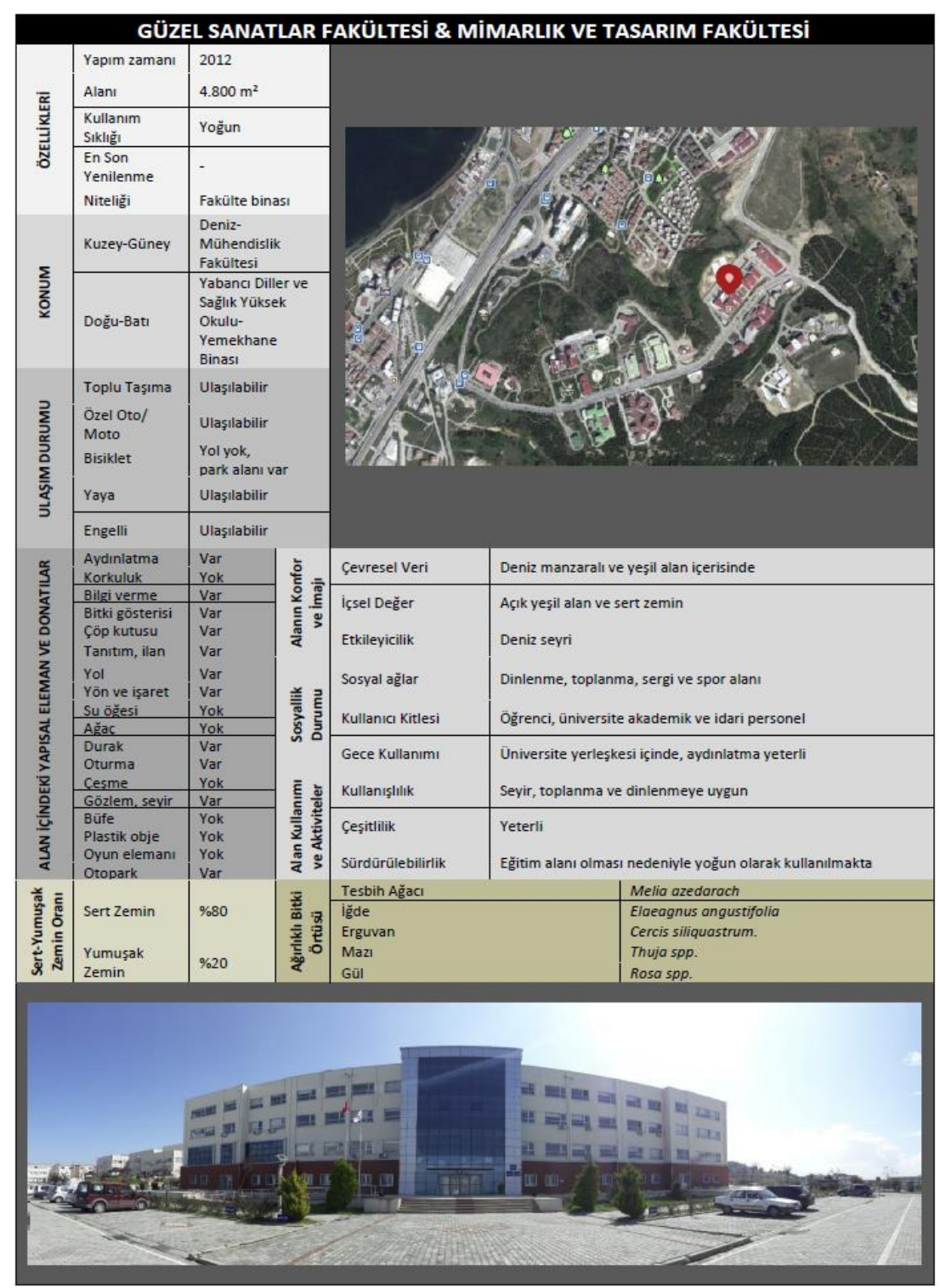

Şekil 11. Güzel sanatlar fakültesi \& mimarlık ve tasarım fakültesi binası ve çevresi kimlik kartı 


\section{ÇOMÜ Mühendislik Fakültesi Binası ve Çevresi}

Mühendislik Fakültesi, 1995-1996 akademik yılında Bilgisayar Mühendisliği ile başladığı eğitim-öğretimine Gıda Mühendisliği, Jeoloji Mühendisliği, Jeofizik Mühendisliği ve Çevre Mühendisliği Bölümleri ile Terzioğlu Yerleşkesindeki yeni binasında devam etmektedir. Fakülte $20.000 \mathrm{~m}^{2}$ alana sahiptir (Anonim, 20201). Yapılan incelemeler ve gözlemler sonucunda fakülte ve çevresiyle ilgili saptanan sorunlar şunlardır: Mühendislik Fakültesinin arkasındaki alanda hem çevre düzenlemesi bulunmamakta hem de toprak kayması olabilecek alanda istinat duvarı eksikliği mevcuttur. Mühendislik Fakültesi ek binası yanındaki üçgen alan bakımsız durumdadır. Hemen bitişiğindeki eğimli köşe gereksiz taş yığınına dönüştürülmüştür. Alanın su oluğunun üzerindeki izgara hem çökmüş hem de içi ağzına kadar toprakla dolduğu için işlevini kaybetmiştir. Bina çatısından gelen ve önünden yere inen tüm yağmur suyu giderleri yürüyüş yolu üzerine bırakılmış ve bir yere bağlanmamıştır. Mühendislik ek binasının ön cephesindeki klima boruları boşta bırakılmış herhangi bir bağlantı yapılmamıştır. Mühendislik ek binası önündeki kaldırımın hemen yanında bulunan üstü açık betonarme kuyu görselliği bozmaktadır. Bina bahçesi girişine konumlandırılan çöp kutuları, kaldırımın bitiminde ve orta yerinde olduğundan kaldırımı takip eden yayaları hem ikiye bölebilir hem de kazaya sebep olabilir. Mühendislik Fakültesi ile Safiye Hüseyin Elbi Heykeli arasındaki kaldırım, ızgara ile daraltılmıştır.

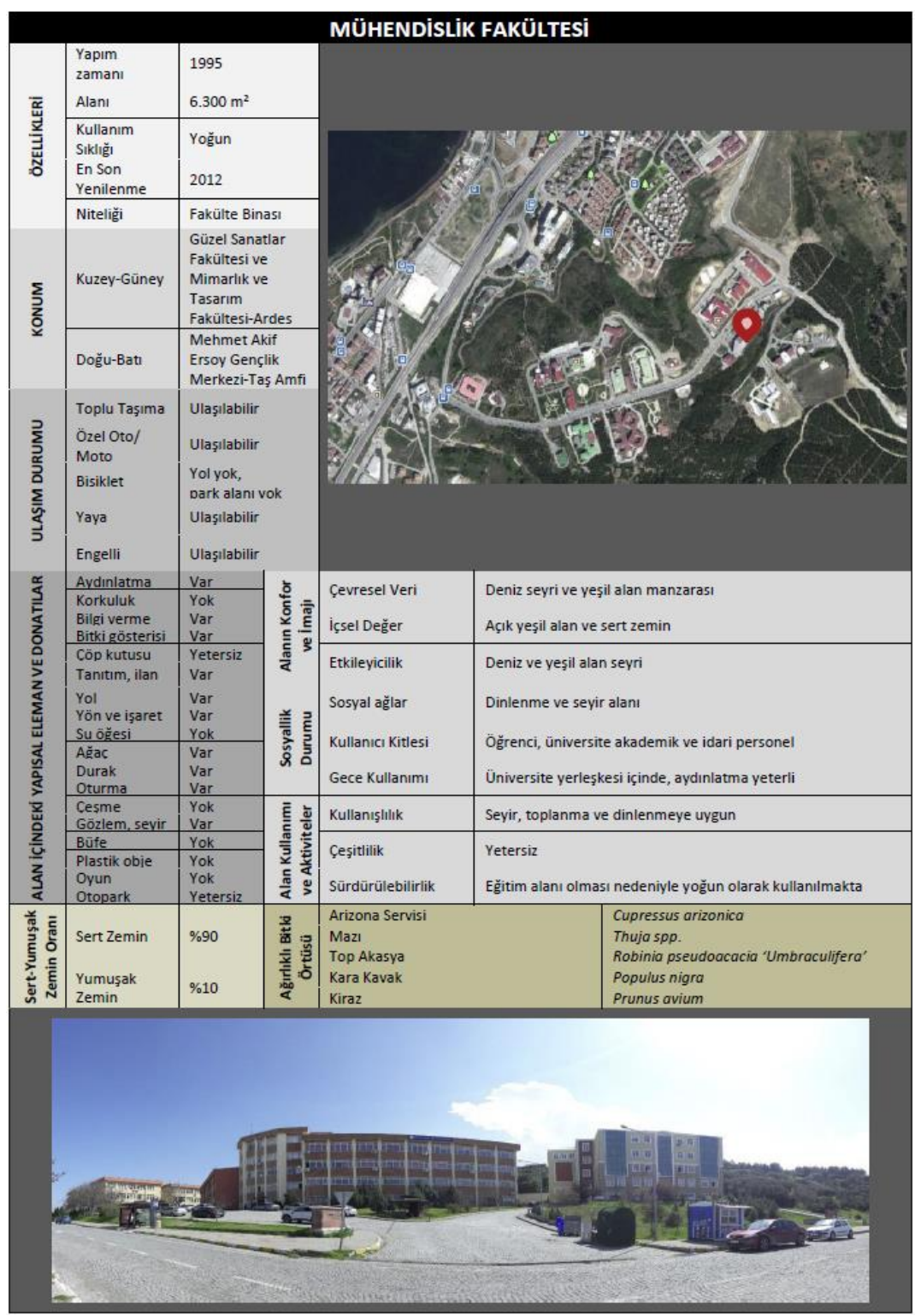

Şekil 12. Mühendislik fakültesi binası ve çevresi kimlik kartı 


\section{ÇOMÜ Spor Bilimleri Fakültesi Binası ve Çevresi}

2014 yılında Terzioğlu Yerleşkesinde yeni binasında faaliyet gösteren ve 16 Şubat 2018 Tarihli ve 30334 sayılı Resmi Gazete'de yayınlanan "Bazı Yükseköğretim Kurumlarına Bağlı Olarak Fakülte ile Yüksekokul Kurulması ve Kapatılması Hakkında Karar" ile Çanakkale Onsekiz Mart Üniversitesi Beden Eğitimi ve Spor Yüksekokulu kapatılarak yerini Spor Bilimleri Fakültesi almıştır (Anonim, 2020j). Yapılan incelemeler ve gözlemler sonucunda fakülte ve çevresiyle ilgili saptanan sorunlar şunlardır: Ardes'ten aşağıya inişte yeni binanın să̆ tarafında kalan görsellikten tamamen uzak olan alan, manzarasına rağmen çöp biriktirme alanına dönüştürülmüştür. Binanın etrafındaki kaldırım kenarlarında olduğu gibi kampüs içinde genel bir bakımsızlık söz konusudur. Çeşitli yabancı otlar tarafından istilaya uğramış birçok duvar ve kaldırım kenarı bulunmaktadır. Bina önündeki gider boruları toprak üstünde bırakılmıştır. Bina çevre sulamasını sağlayan boruların hepsi gelişigüzel döşenmiş ve açıkta bırakılmıştır. Aydınlatma birimleri gerekli derecede sağlamlaştırılmamış, geçici basit çözümlerle desteklenmiştir. Bina karşısına yapılan binanın önündeki kaldırımda yapı malzemeleri bırakılmış, kaldırım önündeki su oluğu toprakla dolmuştur. Bina karşısındaki inşaat yarım bırakıldığından ortaya istenmeyecek görüntüler çıkmıştır. Bina karşısındaki inşaat alanının hemen önündeki kaldırımda, taşların çökmesiyle büyük bir göçük oluşmuştur.

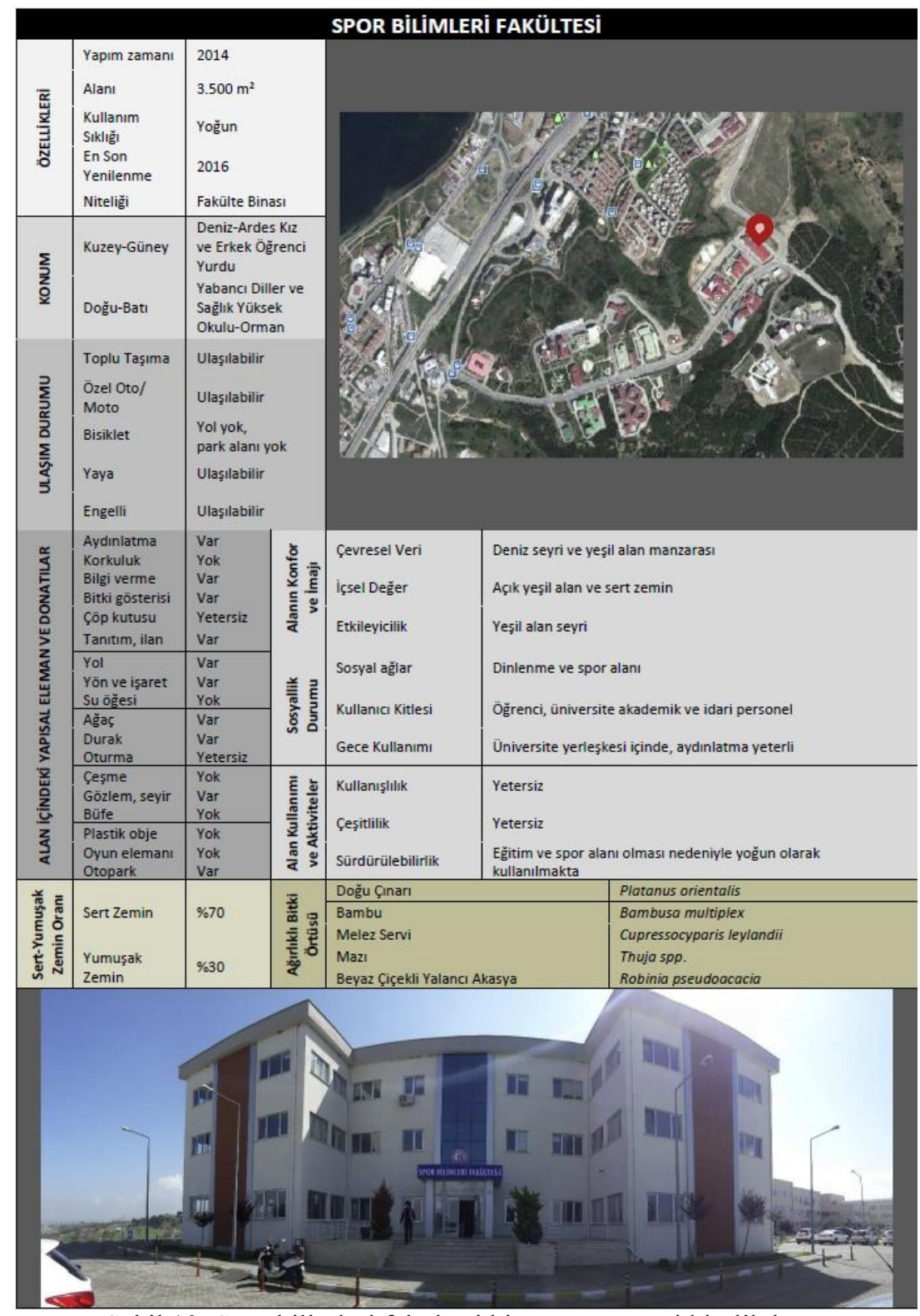

Şekil 13. Spor bilimleri fakültesi binası ve çevresi kimlik kartı 


\section{Sonuç ve Öneriler}

Terzioğlu Yerleşkesi, kuruluşundan bugüne yaklaşık 20 yıl geçmiş olmasına karşın halen fiziki anlamda gelişimini sürdürmektedir. Akademik ve idari anlamda günün gerektirdiği gereksinimler bu gelişmenin devam etmesinde önemli rol oynamaktadır. Bununla birlikte artan yerleşke nüfusunun rekreasyonel gereksinimlerinin de karşılanmasına yönelik talepler de artmaktadır. $\mathrm{Bu}$ yönde özellikle son yıllarda önemli çalışmalar yapılmıştır. Tüm bu gelişmeler ve yapılan çalışmalara karşın Terzioğlu Yerleşkesi’nde yaşanabilirlik açısından özellikle dış mekanlarda birtakım eksiklikler de bulunmaktadır. Buna göre:

- Yerleşke genelinde yönlendirme ve bilgilendirme levhalarında güncelleme ve yenilenme ihtiyaçları vardır.

- Tüm yerleşke genelinde engelsiz yerleşke hedefinin gerçekleştirilmesine yönelik fiziki alt yapı yenilemelerinin yapılması gerekmektedir.

- Yerleşkenin nüfusu her geçen gün artmaktadır. Bu artış kendini ulaşım sisteminde de olumsuz yönde göstermektedir. Taşıt sayısı hızla artmaktadır. Bununla birlikte otopark ihtiyacı da artmaktadır.

- Yol kenarları, kaldırımlar ve hatta yerleşke geneli uygun ilaçlama yöntemi uygulanmadığı için yabancı ot istilasına uğramış durumdadır.

- Kaldırımlar planlanırken uygun yerler tercih edilmediğinden, patika yollar oluşmuştur.

- Kaldırım ve yollarda çökmeler, döşeme eksiklikleri gibi sorunlar ile birlikte onarım aşamasında eksiklikler mevcuttur.

- Yeni yapılan alanlar tamamlanmadan eksik halde bırakılmıştır (sonradan yapılan bordürlerde renk uygulaması yapılmamıştır).

- Çöp kutuları genel olarak sorun teşkil etmektedir. Çöp kutularının adetleri yeterli değildir. Mevcut olanlar da yanlış yerlere konumlandırılmıştır. Sabit çöp kutuları içinden çöpler alındıktan sonra klipsleri takılmadığından, kapaklar rüzgar etkisiyle açılıp kırıkmış izlenimi vermektedir. Çöp konteynırları kapakları hiç kapatılmadığından kötü koku yaymaktadır.

- Yerleşkeye ayrı bir hava katması gereken plastik elemanlar bakımsızlıktan istenilen etkiyi veremiyor.

- Zamanında önlem alınmadığı için rüzgarın ve çevresel faktörlerin etkisi ile formu bozulmuş çok sayıda bitki mevcuttur.

- İklimsel faktörler ve toprak özellikleri göz önüne alınmadan yapılan bitkisel uygulamalar, kimi alanlarda başarısızlık ile sonuçlanmıştır.

- Yerleşke geneli eğimli olduğundan çoğu alanda sulama sıkıntısı yaşanmaktadır. Sulama sistemleri kimi yerlerde toprak üzerine, kimi yerlerde kaldırım üzerinden, kimi yerlerde ise hiç konulmadığından bitkiler ve toprak verimsiz hale gelmiştir.

- Binaların ön taraflarıyla az da olsa ilgilenilmiş, arka tarafları ile hiç ilgilenilmemiştir.

- Binaların çevresinde çok fazla kullanılmayan malzeme mevcut, bu da görüntü kirliliğine yol açmaktadır.

- Kantinler binalara ek oturma birimlerini, kendi çıkarları doğrultusunda düzenleyerek görüntü kirliliği oluşturmuşlardır.

- Yerleşke nüfusunun artışı ile birlikte rekreasyon alanlarına olan ihtiyaç ta artmaktadır. Bu amaçla özellikle spor açık spor alanları geliştirilmelidir.

- Personel eksikliğinden dolayı fakülte çevreleri bile bakımsız durumda iken, yerleşke genelinin bakımsız olması kaçınılamaz hale gelmiştir.

Tüm bu gelişmeler ve yapılan çalışmalara karşın Terzioğlu Yerleşkesi'nde yaşanabilirlik açısından özellikle dış mekanlarda yenileme, bakım ve onarım çalışmalarına gerekli önemin verilmesi gerekmektedir. Yerleşkeler, kentin önemli bir alanını kaplayan açık yeşil alanlardır ve bu alanların planlaması ve tasarımına önem verilmelidir.

Not: Bu çalışma, Çanakkale Onsekiz Mart Üniversitesi Bilimsel Araştırma Projeleri Koordinasyon birimince desteklenmiştir. Proje Numarası: FBA-2015-49. 


\section{Kaynaklar}

Anonim, 2020a. https://www.comu.edu.tr/tarihce, Erişim: 12.05.2020

Anonim, 2020b. http://tip.comu.edu.tr/, Erişim: 12.05.2020

Anonim, 2020c. http://sbf.comu.edu.tr/tarihcemiz.html, Erişim: 12.05.2020

Anonim, 2020d. http://turizm.comu.edu.tr/tarihce.html, Erişim: 12.05.2020

Anonim, 2020e. http://ziraat.comu.edu.tr/, Erişim: 14.05.2020

Anonim, 2020f. http://fef.comu.edu.tr/fakultemiz/genel-tanitim.html, Erişim: 14.05.2020

Anonim, 2020g. http://denbiltek.comu.edu.tr/, Erişim: 14.05.2020

Anonim, 2020h. http://gsf.comu.edu.tr/hakkimizda/hakkimizda.html, Erişim: 14.05.2020

Anonim, 20201. http://muhendislik.comu.edu.tr/genel-bilgiler/hakkimizda.html, Erişim: 14.05.2020

Anonim, 2020j. http://sporbf.comu.edu.tr/tarihce.html, Erişim: 14.05.2020

Bağcı, Ö., 2010. Yenişehir (Mersin) kentsel alanında peyzaj mimarlığı disiplini kapsamında kentsel gönenç araştırması. Çukurova Üniversitesi Fen Bilimleri Enstitüsü Peyzaj Mimarlığı Anabilim Dalı, Yüksek Lisans Tezi. $111 \mathrm{~s}$.

Ertekin, M., Çorbacı, Ö.L., 2010. Üniversite kampüslerinde peyzaj tasarımı (Karabük üniversitesi peyzaj projesi örneği). Kastamonu Üniversitesi Orman Fakültesi Dergisi. 10 (1): 55-67.

Oğuz, D., 1998. Kent parkı kavramı yönünden Ankara kent parklarının kullanım olgusu üzerine bir araştırma. Ankara Üniversitesi Fen Bilimleri Enstitüsü Peyzaj Mimarlığı Anabilim Dalı, Doktora Tezi. 290 s.

Öztürk, S., Özdemir, Z., 2013. Kentsel açık ve yeşil alanların yaşam kalitesine etkisi "Kastamonu örneği”" Kastamonu Üniversitesi Orman Fakültesi Dergisi. 13 (1): 109-116.

Pamay, B., 1979. Park-Bahçe ve Peyzaj Mimarisi, İ.Ü. Orman Fakültesi Yayınları, No: 2486-264, 263 s. İstanbul.

Sağlık, A., 2014. Çanakkale kenti rekreasyon potansiyelinin kentlerin yaşanabilirliği açısından değerlendirilmesi. ÇOMÜ Sosyal Bilimleri Enstitüsü Peyzaj Mimarlığı Anabilim Dalı, Doktora Tezi. 200 s.

Sönmezler, K., 2003. Modern mimarinin kentsel deney alanı: Üniversite tasarımı. Mimar Sinan Üniversitesi Fen Bilimleri Enstitüsü, Doktora Tezi. 384 s.

Tanrıverdi, F., 1975. Peyzaj mimarisi, bahçe sanatının temel prensipleri ve uygulama metotları. Atatürk Üniversitesi Ziraat Fakültesi Yayınları, No: 196-29, 367 s.

Yıldırım, A., Hacıhasanoğlu, R., 2011. Sağlık çalışanlarında yaşam kalitesi ve etkileyen değişkenler. Psikiyatri Hemşireliği Dergisi. 2 (2): 61-68.

Yıldızc1, A.C., 1982. Kentsel yeşil alan planlaması ve İstanbul örneği. İstanbul Teknik Üniversitesi Mimarlık Fakültesi, Doçentlik Tezi (Yayınlanmamış). $218 \mathrm{~s}$

Yılmaz, S., 2015. Bir kampüs açık mekanının peyzaj tasarımı Süleyman Demirel Üniversitesi Orman Fakültesi binas1. Kastamonu Üniversitesi Orman Fakültesi Dergisi. 15 (2): 297-307. 